\title{
Fused Salt Processing of Impure Plutonium Dioxide to High-Purity Plutonium Metal
}

\author{
L. J. Mullins \\ D. C. Cillistensen \\ B. R. Babcock
}

PARTIRS OF THAO BEFEFT ARE ILLEGBA.E.

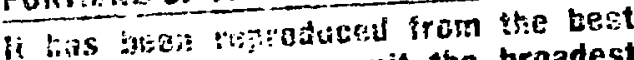
aiaiinise copy to permit the broadest pussibic arailabisty.

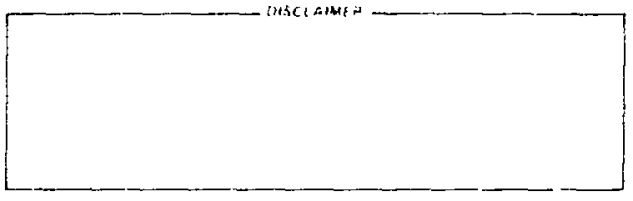


CONTENTS

PAGE

ABSTRACT . . . . . . . . . . . . . . . . . . . . . . . . . . . . . 1

I. INTRODUCTION . . . . . . . . . . . . . . . . . . . . . . . . 1

II. SCHEMATIC FLOWSHEET FOR THE CONVERSION OF PLUTONIA SCRAP TO. . . 2 HIGH-PURITY METAL .

II I. DIRECT OXIDE REDUCTION PROCESS . . . . . . . . . . . . . . . . . 3

A. Basic Principles... . . . . . . . . . . . . . . . 3

B. Oxide Feed Specifications. . . . . . . . . . . . . . . . 3

1. Physical Properties . . . . . . . . . . . . . . . . 3

2. Isotopic Composition... . . . . . . . . . . . . 4

3. Chemical Purity . . . . . . . . . . . . . . . . . . 4

C. Equipment and Materials . . . . . . . . . . . . . . 5

D. Operating Procedure . . . . . . . . . . . . . . . . 6

E. Discussion. . . . . . . . . . . . . . . . . . . 9

F. Results. . . . . . . . . . . . . . . . . . . 10

IV. ELECTROREFINING PROCESS. . . . . . . . . . . . . . . . . . . . 11

A. Basic Principles... . . . . . . . . . . . . . . . . . 11

B. Metal Feed Specifications . . . . . . . . . . . . . . . 12

1. Physical Properties. . . . . . . . . . . . . . . . . . . 12

2. Chemical Purity. . . . . . . . . . . . . . . . 12

C. Equipment and Materials . . . . . . . . . . . . . . . 12

D. Operating Procedure . . . . . . . . . . . . . . . . . . . . 14

E. Discussion and Results . . . . . . . . . . . . . . . . . . . 16

v. CONVERSION OF JMPURE PLUTONIA TO HIGH-PURITY METAL . . . . . . . 18

VI. FUTURE WORK . . . . . . . . . . . . . . . . . . . . . . . . 21

RFFERENCES . . . . . . . . . . . . . . . . . . . . . 21 


\title{
FUSED SALT PROCESSING OF IMPURE PLUTONIUM DIOXIDE TO HIGH-PURITY PLUTONIIN METAL
}

by

L. J. Mullins, D. C. Christensen, and

B. R. Babcock

\begin{abstract}
We have developed a process for converting impure plutonium dioxide ( $296 \%$ pure) to high-purity plutonilim metal $(>99.9 \%)$. The process consists of reducing the oxile to an impure plutonium metal intermediate with calcium metal in molten calcium chloride. The impure intermediate metal is cast into an anode and electrorefined to produce high-purity plutonium metal.

The oxide reduction step is being done now on a $0.6-\mathrm{kg}$ scale with the resulting yield being $>99.5 \%$. The electrorefining is being done on a 4.0-kg scale with the resulting yield being $80-85 \%$. The purity of the product, which averages $99.98 \%$, is essentially insensitive to the purity of the reed metal. The yield, however, is directly dependent on the chemical composition of the feed.

To date, approximately $250 \mathrm{~kg}$ of impure oxide has been converted to pure metal by this processing sequence. The availability of impure plutonium dioxide, together with the need for pure piutonium metal, makes this sequence a valuable plutonium processing tool.
\end{abstract}

\section{INTRODUCTION}

The use of electrorefining (ER) for the routine processing of impure plutonium metais and alloys to high-purity metal has been an established procedure at Los Alamos since 1964. During the period 1964-1977, $1930 \mathrm{~kg}$ of metal fabrication scrap of $<99 \%$ purity was converted to $1568 \mathrm{~kg}$ of high-purity plutonium metal, >99.95\% purity, in 653 runs. ' 
The use of direct oxide reduction (DOR) procedures for the routine processing of plutoniun dioxide to metal is a fairly recent inovation. Processes for the conversion of $200-\mathrm{g}$ batches of ${ }^{238} \mathrm{PuO}_{2}$ and ${ }^{239} \mathrm{PuO}_{2}$ to metal were developed in 1975-1976. ${ }^{2}$ The process was later extended to the 400- and 700-g scale for ${ }^{239} \mathrm{PuO}_{2}$ operations. ${ }^{3}$

For the past 3 years, we used the combination of DOR/ER for the rcutine recycle of impure ${ }^{239} \mathrm{PuO}_{2}$ to high purity metal. The recent shortage of plutonium meta $1,{ }^{4}$ the availability of plutonium oxide scrap, and the cost effectiveness of the process have resulted in increased interest in this processing route.

II. SCHEMATIC FLOWSHEET FOR THE CONVERSION OF PLUTONIA SCRAP TO HIGH-PURITY METAL

The process schematic for the conversion of plutonia scrap to pure metal is given in Fig. 1. This flowsheet is considered in more detail in Sec. $V$. Plutonia scrap is reduced to impure metal that is electrorefined to produce highpurity metal.

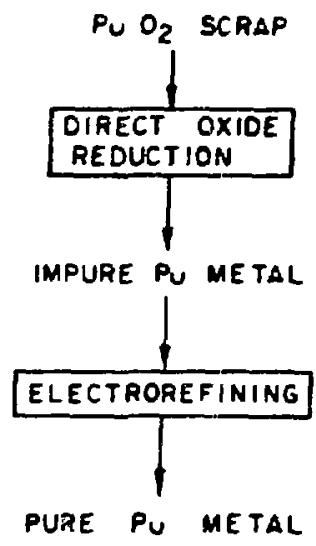

Fig. 1. Converston of plutonta scrap to pure metal. 
III. DIRECT OXIDE REDUCTION PROCESS

\section{A. Basic Principles}

A review of processes for reducing plutonium compounds to metal is given in Ref. 2. Most plutonium facilities react either $P_{4 F_{4}}$ or a mixture of $(75 \mathrm{~mol} \%$ $\mathrm{PuF}_{4}-25 \mathrm{~mol}_{\mathrm{O}} \mathrm{PuO}_{2}$ ) with calcium. An initiator of $\left(\mathrm{Ca}+\mathrm{I}_{2}\right)$ or a pyrotechnic initiator is used in the $\mathrm{PuF}_{4}$ reductions.

There are many advantages to reducing $\mathrm{PuO}_{2}$ directly to metal. They include

(a) Ease of preparation of $\mathrm{PuO}_{2}$. Plutonium metal and all of it.s compounds, except the phosphate, are converted to $\mathrm{PuO}_{2}$ when they are heated in air.

(b) Availability of $\mathrm{PuO}_{2}$. Plutonium dioxide constitutes the bulk of scrap materials in storage. The usual form is foundry oxide, which is quite unreactive and cannot be converted to $\mathrm{PuF}_{4}$ by conventional hydrofluorination procedures. This oxide, however, can be reduced by DOR.

(c) Decrease in pe:-: onnel neutron exposures. Personnel neutron exposures are reduced by eliminating the use of $\mathrm{PuF}_{4}$ (that is, $\mathrm{PuF}_{4}$ is a high neutron emitter because of the $(\alpha, \eta)$ reaction, ${ }^{19} \mathrm{~F}(\alpha, \eta)^{22} \mathrm{Na}$.

The reduction of $\mathrm{PuO}_{2}$ by $\mathrm{Ca}$ metal is done in a $\mathrm{CaCl}_{2}$ solvent. The reaction is

$$
\mathrm{PuO}_{2}(\mathrm{~s})+2 \mathrm{Ca}(\ell)+11 \mathrm{CaCl}_{2}(\ell) \longrightarrow 2 \mathrm{CaO} \cdot 11 \mathrm{CaCl}_{2}(\ell)+\mathrm{Pu}(\ell)
$$

Thus, the $\mathrm{CaCl}_{2}$ dissolves the $\mathrm{CaO}$ by-product permitting coalescence of plutonium metal in a massive pool.

\section{B. Oxide Feed Specifications}

1. Physical Properties. We have no physical property limitations on the oxide feed. High-fired, unreactive oxides, as well as the more reactive oxides prepared by the calcination of oxalates and peroxides, can be reduced to metal with high yields. ${ }^{2}$ Most of the oxides we process are either foundry oxides, resulting from the burning of plutonium casting skulls, or impure oxide resulting from the calcination of $\mathrm{Pu}_{2}\left(\mathrm{C}_{2} \mathrm{O}_{4}\right)_{3} \cdot \mathrm{xH}_{2} \mathrm{O}$. This latter oxide is usually the product from the recovery of plutonium wastes by aqueous methods. 
2. Isotopic Composition. We have no plutonium isotopic limitations on oxide feed. We have routinely processed feeds containing as much as $20-23 \%$ $240 \mathrm{Pu}$ with no variation in procedures and no decrease in yields.

3. Chemical Purity. Present chemical purity specifications for oxide feed are given in Table $I$. These specifications srve as a guide for nuclear

TABLE. I

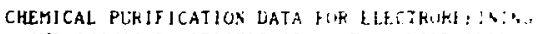
AND CHEHICAL SPECIFILATIUAS FOR OXIDL IH.J.

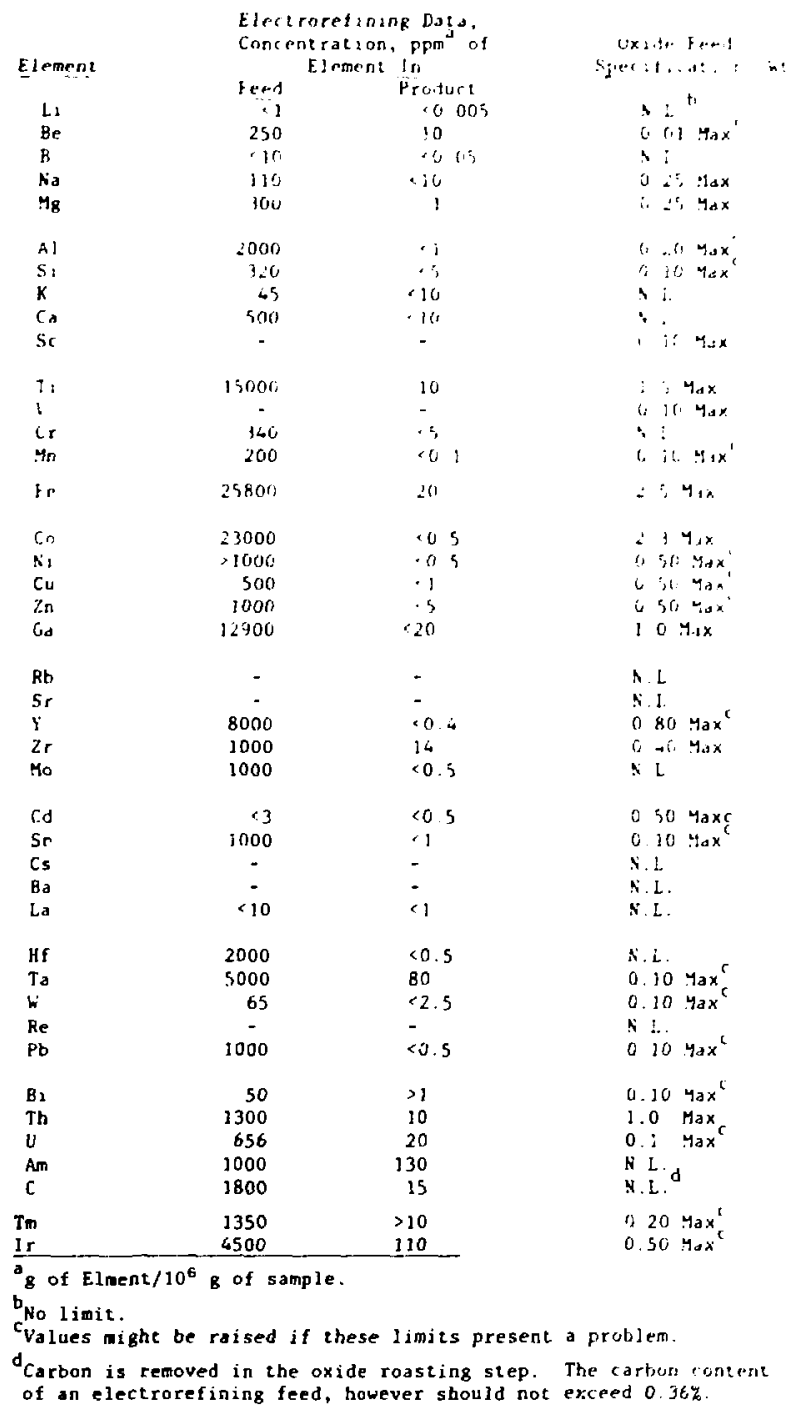


material managers in selecting processing routes. Oxides that meet these specifications are processed by DOR/ER. In most cases, product metal purity requirements and electrorefining limitations set the specifications. As shown in Table I, some of the specifications are based on experimental data. In other cases, (zirconium and thorium), phase diagrams were used to calculate the concentration of the elemental impurities that would permit $90 \%$ depletion of the plutonium anode before solidification occurs at $750^{\circ} \mathrm{C}$. Table I serves only as a guide. The limitations on purity are probably conservative and might be changed if operational data show they are ton restrictive.

The specification for plutonium concentration is that the plutonium value should be equal to or greather than $85 \%$. This corresponds to an oxide purity of $96.4 \%$ for the usual isotopic mix. Again, this number is a guide for screening oxide feeds. More definitive work could result in a relaxation of this criterion.

C. Equipment and Materials

The oxide reduction equipment is shown in Fig. 2. The reduction is done in a magnesia crucible contained in a tantalum safety can and a stainless steel loading can. The loading can is contained in a sealed furnance tube having an argon atmosphere and is heated by a resistance furnace, Lindberg Model 6015S. The reaction mixture is stirred by a tantalum stirrer fitted with two sets of oppositely pitched impellers. As the stirrer is rotated clockwise, the bottom impeller lifts the plutonia into the molten sait and the top impeller pulls the calcium metal down into the molten salt. Temperature is measured by a ChromelAlumel thermocouple immersed in the melt and protected by a tantalum-nickel sheath. The outer tube is tantalum and the inner tube is nickel. The tantalum is resistant to the components of the reaction mixture and the nickel protects the tantalum from air oxidation and provides mechanical strength. The upper ends of the tantalum and nickel tubes are welded together.

The magnesia crucibles are highly vitrified bodies and are fabricated commercially.

The calcium chloride is Mallinckrodt's 4104 Anhydrous Calcium Chloride. Before using, we dry it under vacuum at $225^{\circ} \mathrm{C}$ for approximately 5 days and then isostatically press it into cylinders.

The calcium metal is Pfizer's Redistilled-Grade, 6-mesh nodules. 


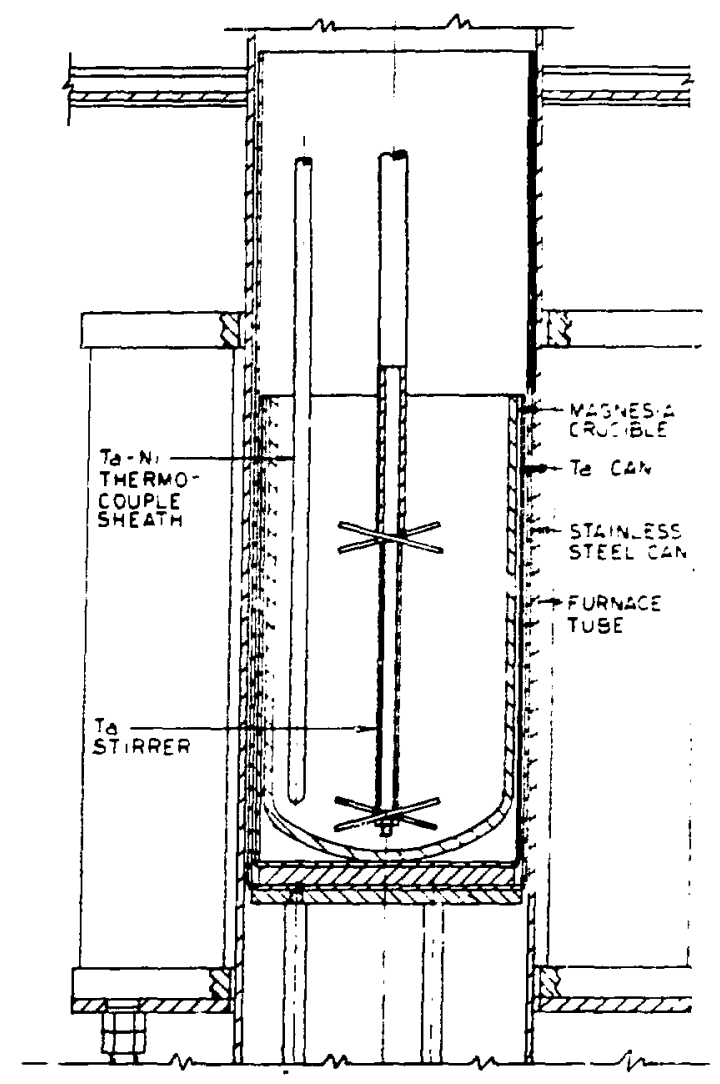

Fig. 2. Plutonia reduction equipment.

\section{Operating Procedure}

Approximately $700 \mathrm{~g}$ of roasted plutonia (see Sec. $\dot{V}$ for roasting conditions) are poured into a magnesia crucible (Los Alamos body A-480). With the crucible in the vertical position, the $\mathrm{PuO}_{2}$ is covered with a 100-8 layer of anhydrous calcium chloride powder. The $301 \mathrm{~g}$ of calcium metal is then placed on this powder. Finally, a $3.5 \mathrm{~kg}$ cylinder of $\mathrm{CaCl}_{2}$ is placed on the calcium. The crucible is loaded into the tantalum safety can, which is placed in the stainless loading can. This assembly is then placed in the furnace tube and the cover plate is bolted in place. A vacuum is pulled on the furnace tube, which is checked for gas tightness. The furnace tube is then filled with argon gas to 4 psig.

The crucible is heated at a maximum rate of $200^{\circ} \mathrm{C} / \mathrm{h}$ to the melting point of $\mathrm{CaCl}_{2}, 772^{\circ} \mathrm{C}$. The thermocouple sheath and stirrer are then lowered into the melt 
to the position shown in Fig. 2. When the temperature reaches $800^{\circ} \mathrm{C}$, stirring is initiated at $200 \mathrm{rpm}$. An immediate increase in temperature occurs. After 1 to 2 min at $200 \mathrm{rpm}$, a leveling of the temperature takes place, the stirring is then increased slowly to $400 \mathrm{rpm}$, and then increased to $600 \mathrm{rpm}$. The temperature profile for a typical run is giver in Fig. 3. The reaction usually is complete in less than 5 minutes; however, stirring is continued for a total time of $15 \mathrm{~min}-$ utes. If the temperature of the melt reaches $839^{\circ} \mathrm{C}$ (the melting point of calcium: metal) before a $600-\mathrm{rpm}$ stirring rate is achieved, the rate is immediately increased to $600 \mathrm{rpm}$. This is done to minimize the reaction

$$
\mathrm{Ca}(\ell)+\mathrm{MgO} \longrightarrow \mathrm{CaO}+\mathrm{Mg}(\ell) .
$$

This practice ensures thorough stirring and minimal contact of calcium with the magnesia crucible. Usually, the maximum temperature reached is $875^{\circ} \mathrm{C}$. A drop in temperature indicates completion of the reduction. Upon completion of the 15minute stirring period, the stirrer speed is slowly decreased to zero rpm. By this time, the temperatu:e levels out at $\sim 850^{\circ} \mathrm{C}$. (Note. The temperature must be kept above $835^{\circ}$ to achieve a high solubility of $\mathrm{CaO}$ in $\mathrm{CaCl}_{2} .{ }^{5}$ ) To promote good metal collection, the stirrer is raised 2 inches, reactivated, and the speed slowly increased to $200 \mathrm{rpm}$. After 2 minutes at $200 \mathrm{rpm}$, the speed is slowly reduced to $0 \mathrm{rpm}$ and the stirrer is allowed to drain for 5 minutes. The stirrer and thermocouple sheath are then raised from the melt and the furnace is shut off. The furnace is allowed to cool for at least 4 hours before unloading. The stainless loading can is removed from the furnace and inverted to remove its

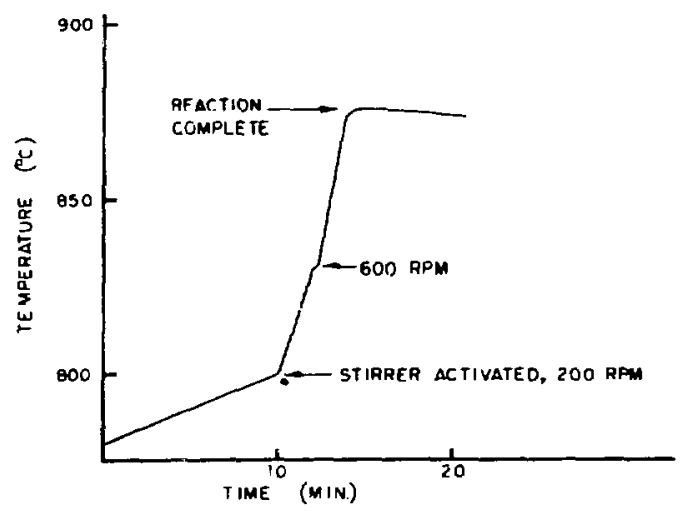

Fig. 3. Temperature vs time, typical reduction. 
contents. The metal button is removed from the magnesia crucible by breaking away the bottom of the crucible. As shown in Fig. 4, the button separates cleanly from the salts and crucible and can easily be removed by breaking away the bctrom of the crucible. The residues consisting of the $\mathrm{CaCl}_{2}-\mathrm{CaO}$ salt and magnesia crucible are assayed for piutonium by neutron coincidence counting.

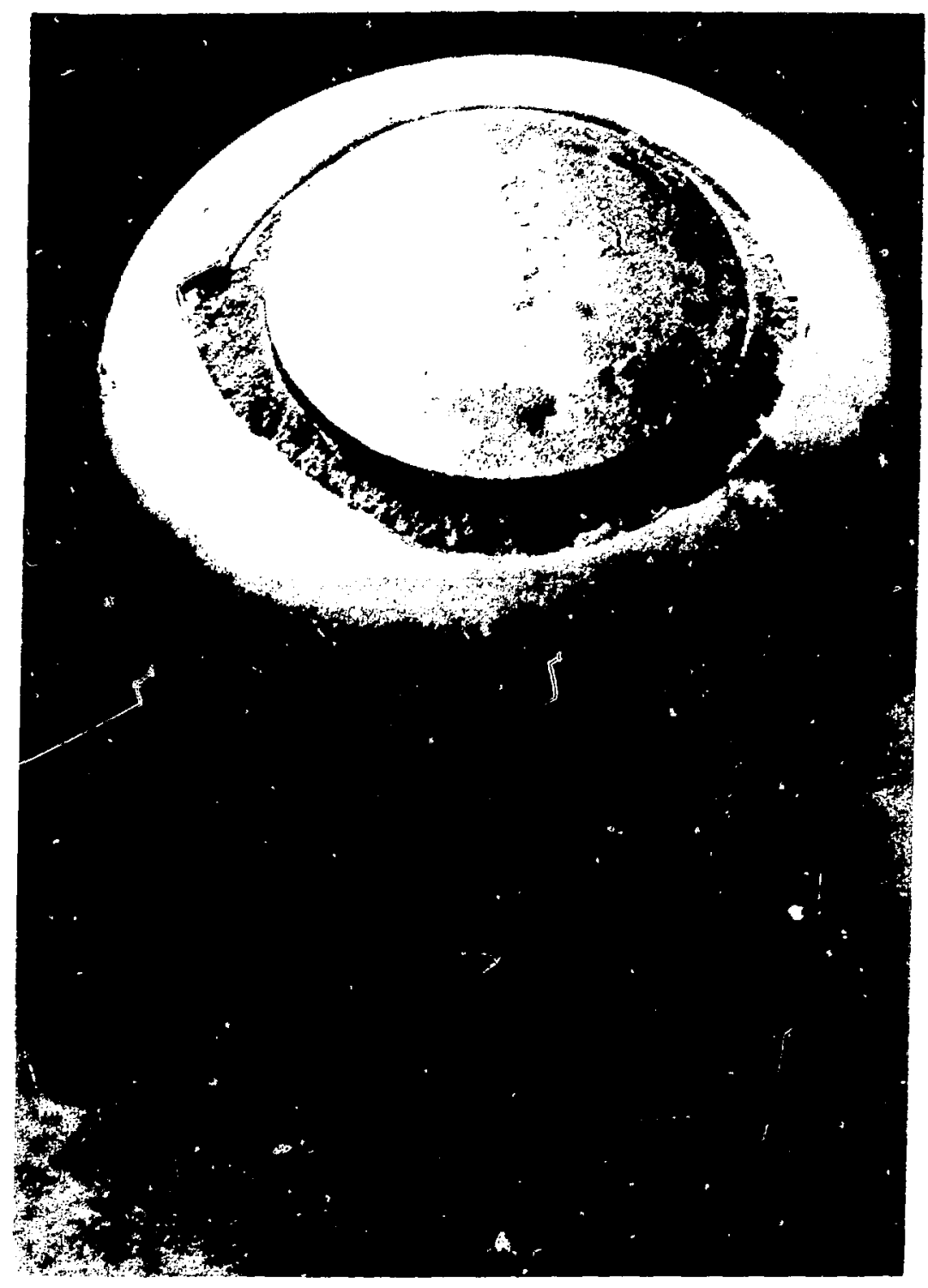

Fig. 4. DOR product and residues. 
The success of DOR is dependent on many parameters. ${ }^{2}$ The four most imporLant are

(i) Stirring. Effective stirring of the reaction mixture is absolutely essential. High density $\mathrm{PuO}_{2}\left(11.46 \mathrm{~g} / \mathrm{cm}^{3}\right)$ must be lifted off the bottom of the crucible and disyersed into molten $\mathrm{CaCl}_{2}$. Low-density calcium metal $\left(1.54 \mathrm{~g} / \mathrm{cm}^{3}\right)$ must be stirred into the $\mathrm{CaCl}_{2}$ so it can react with $\mathrm{PuO}_{2}$. (In additic $\mathrm{n}$, dispersion of calcium metal into the melt minimizes attack of liquid calcium metal on the MgO crucible.) The reaction by-product, $\mathrm{CaO}$, must be dissolved in the $\mathrm{CaCl}_{2}$ as it is formed to permit good collection of the plutonium metal product and good phase separation of plutonium metal from the $\mathrm{CaCl}_{2}-\mathrm{CaO}$ melt. Poor stirring will result in incomplete reduction of $\mathrm{PuO}_{2}$, poor metal collection, and poor metal-salt phase separation.

(b) Solvent capacity. The phase diagram for the $\mathrm{CaCl}_{2}-\mathrm{CaO}$ system ${ }^{5}$ shows that the solubility of $\mathrm{CaO}$ in $\mathrm{CaCl}_{2}$ is $18.5 \mathrm{~mol} \%$ at $835^{\circ} \mathrm{C}$. This solubility sets the maximum ratio of $\mathrm{g} \mathrm{Pu} / \mathrm{g} \mathrm{CaCl}_{2}$ at a value of 0.245 . Attempts to achieve this value $^{2}$ were unsuccessful and a value of $0.17 \mathrm{~g} \mathrm{Pu} / \mathrm{g} \mathrm{CaCl}$ was established for practical operating conditions. It should be realjzed that virtually all of the oxide impurities present in the oxide feed also react with calcium metal resulting in the formation of $\mathrm{CaO}$, namely,

$$
\mathrm{Na}_{2} \mathrm{O}+\mathrm{Ca} \longrightarrow \mathrm{CaO}+2 \mathrm{Na} \text {. }
$$

If the impurities are primaxily light element oxides, enough CaO can be produced to interfere with the plutonia reduction. This can result in incomplete reduction of $\mathrm{PuO}_{2}$ and poor plutonium metal collection. Fortunately, these poor runs are easily identified and the plutonium materials can be recycled into another run. This is accomplished by cleaving the bottom of the salt residue away from the main body of the $\mathrm{CaCl}_{2}-\mathrm{CaO}$ and loading this salt bottom and plutonium metal into a new run. The top portion of the salt usually contains < $g$ plutoniun.

(c) Temperature measurement. Direct measurement of the salt temperature is essential in the DOR process. Stirrer initiation and stirring rates are controlled by temperature measurement (see Sec. III.D). Control of the melt temperature is important in achieving maximum solubility of $\mathrm{CaO}$ in $\mathrm{CaCl}_{2}$ and in mininizing 
the attack of $\mathrm{MgO}$ by liquid calcium. Progress of the reduction is easily followed by observing the melt's temperature trace, which clearly shows initiation and completion of the reaction (see Fig. 3 ).

(d) Dry reagents. The importance of using anhydrous $\mathrm{CaCl}_{2}$ and $\mathrm{PuO}_{2}$ cannot be overemphasized. Extreme care must be exercised in handiing $\mathrm{CaCl}_{2}$ because it is so hygroscopic. Calcium chloride can be dried easily in vacuum-drying ovens without any appreciable hydrolysis. The dried powder, however, must be handled in dry atmosphezes to avoid water pickup. Once the $\mathrm{CaCl}_{2}$ cylinders are pressed, water pickup is less of a problem. However, all cylinders are stored in vacuum drying ovens at $225^{\circ} \mathrm{C}$ after pressing. If moisture remains in the reagents, many problems arise. Foaming during the heat up and melting is most common. This results in a loss of $\mathrm{CaCl}_{2}$ as a solvent for CaO. In adoition, at the high reaction temperature, water reacts with both $\mathrm{CaCl}_{2}$ and alcium to form CaO. This further reduces the solvent capazity of tine $\mathrm{CaCl}_{2}$ for the intended CaO reaction by-product. Regardless of mechanism, the result is a poor reduction yield. These runs generally must be rerun with a fresh $\mathrm{CaCl}_{2}$ salt cake.

\section{F. Results}

The results of a typical plutonia reduction are given in Table II. Typically, $700 \mathrm{~g}$ of oxide feed containing $595 \mathrm{~g}$ of plutonium is reduced to metal with a yield of $99.5 \%$. The plutonium held up on the tantalum stirres is recycled to the next run. Essentially no purification is achieved in DOR. The product contains all of the impurities present in the oxide feed plus those introduced by DOR reagents, namely, calcium, boron, and carbon (see Sec. V).

More than $250 \mathrm{~kg}$ of impure oxide have been converted to impure metai by DOR. 
TABLE II

\section{RESULTS OF TYPICAL PLUTONIA \\ REDUCTIONS (700 \& Scale)}

\begin{tabular}{lr} 
Feed Materials & $\frac{\mathrm{Pu}}{595}$ \\
700 g Oxide & 20 \\
21 \& Metal on Stirrer & \\
301 \& Ca netal & \\
$3.6 \mathrm{~kg} \mathrm{CaCl}{ }_{2}$ & \\
Reaction Products & 592 \\
\hline 614 \& Metal Button & 20 \\
21 \& Metal on Stirrer & 3 \\
Residues (salt and crucibles) & $99.5 \%$ \\
\hline
\end{tabular}

IV. ELECTROREFINING PROCESS

A. Basic Principles

Flutonium electrorefining principles are simmarized in Ref. 1. Briefly, the process consists of oxidizing plutonium from an impure metal feed at the anode and reducing it to pure metal ar the cathode, that is,

$\begin{array}{ll}\text { Allode : } & \mathrm{Pu}(\text { impure, } 2) \longrightarrow \mathrm{Pu}^{+3}+3 e^{-} \\ \text {Cathode. } & \mathrm{Pu}^{+3}+3 e^{-} \longrightarrow \mathrm{Pu} \text { (pure, 2) }\end{array}$

Net Reaction: Pu (inpure, $\ell$ ) $\longrightarrow$ Pu (pure, $\ell$ ).

The process is done at $740^{\circ} \mathrm{C}$ in a molten salt consisting of $\mathrm{NaCl}-\mathrm{KCl}-\mathrm{PuF}_{3}$, under near-equilibrium conditions. Virtuaily all of the impuities concentrate in the anode. Of the impurities usually present in plutoniun, only anericium concencrates in the salt. 
1. Physical Properties. The feed to ER must be metal. It can be impure plutonium metal or alloys of plutonium. The metal is vacuum-cast into a cylinder prior to electrorefining. The primary purpose of the casting is to put the metal into the proper geometry for loading $4 \mathrm{~kg}$ of plutonium into the anode cup. The vacuum-casting also removes volatile metallic impurities such as calcium and mag. nesium and concentrates impurities such as $\mathrm{PuO}_{2}$ in the casting residue. The presence of small amounts of $\mathrm{PuO}_{2}$ will not nisgate the electrorefining; however, excessive amounts should be avoided. For tnis reason, oxidized ancide cylinders ar. thoroughly brushed before loading.

2. Chemical Purity. Because no purification takes place in DOR, the purit $\gamma$ of the ER feed is dependent on the DOR feed. In practice, the ER feed is inferior because all of the ragent impurities of the DOR process are scavanged by thi: active plutonium metal product of DOR.

One of the design goals of ER is to deplete at least $90 \%$ of the plutonium anode before solidification or phase separation of the anode terminates the elec* trorefining. (For a thorough discussion of this point, see Ref. 1.) As stated in Sec. III. B. 3 and seen in Table I, mose of the oxide chemical specifications are based on ER empirical results. In sone cases (zirconium, thorium, and carbon) phase diagrams were used to calculate the initial impurity concentration in the feec metal that would parmit $90 \%$ anode depletion. Thus the data in Table I serve as a guide only and any change in operating conditions can affect the extent of anode depletion. In addition, the values in Table I can be changed when empirical results indicate that it is appropriate.

\section{Equipment and Materials}

The electrorefining equipment is shown in Fig. 5. The process is performed in a double-cupped magnesia crucible. As in DOR, the crucible is contained in a tantalum safety can and a stainless steel loading can. The loading can is contained in an identically sealed furnace tube and heated by an identical resistance furnace (Lindberg Modei 6015S) as in the DOR proc'ss (see Fig. 2).

A schematic of the electrorefining cell is given in Fig. 6. The electrorefining crucible consists of two magnesia crucibies cemented together. The inner cup contains the impure metal feed. Both the impure metal and the molten salt electrolyte are stirred by a magnesia stirrer. A tungsten rod suspended in the 


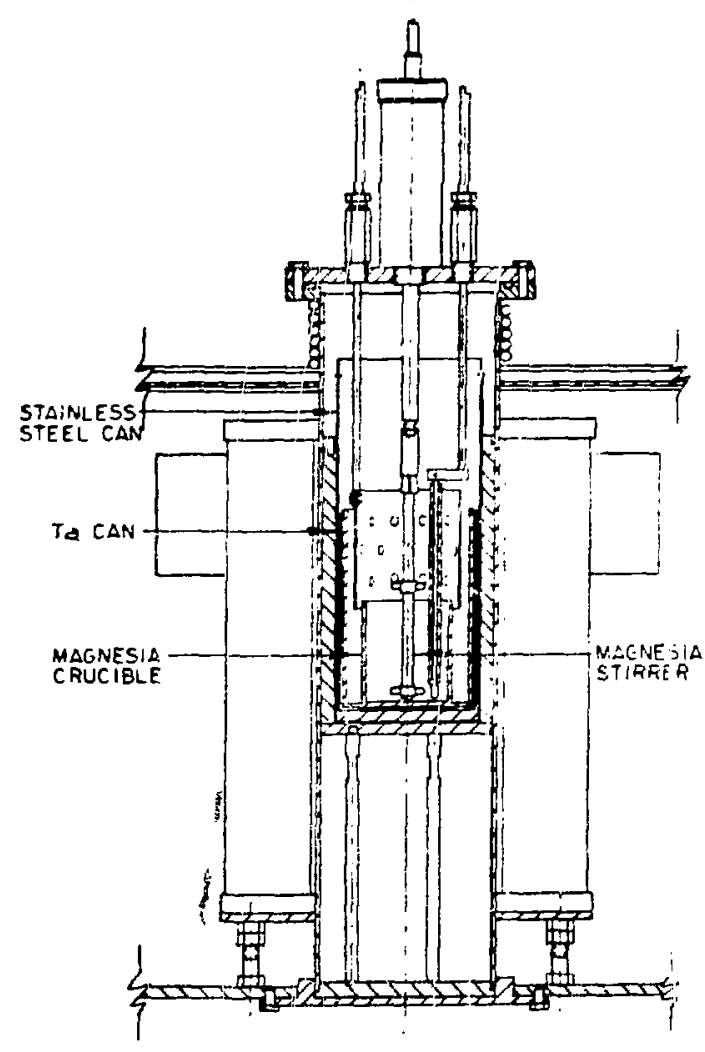

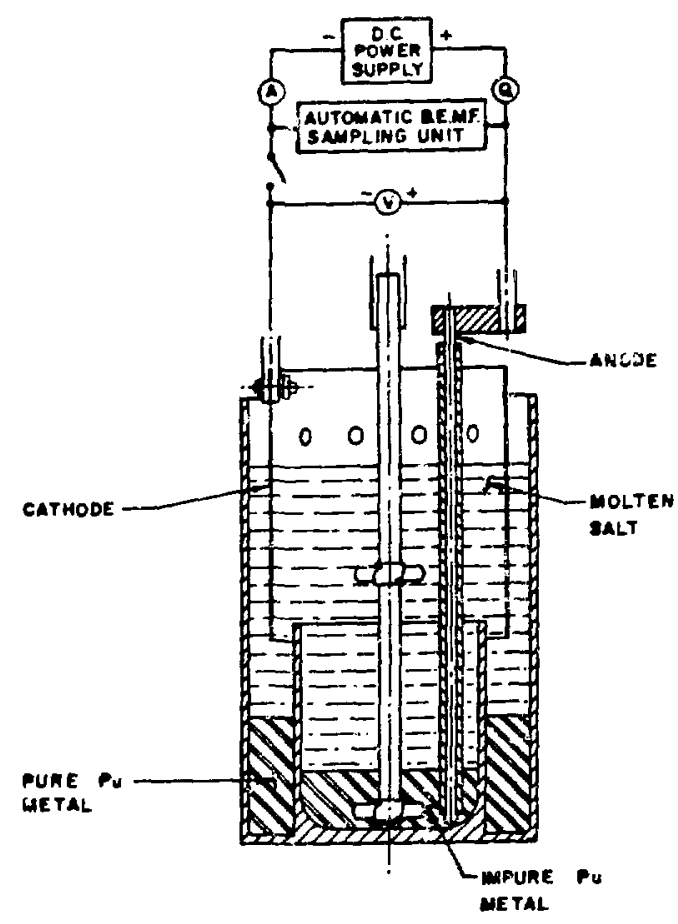

Fig. 6. Schematic of electrorefining cell.

Fig. 5. Electrorefining process equipment.

impure metal pool serves as the anode rod. The anode rod is electrically insulated with a magnesia sleeve. A cylindrically shaped sheet of tungsten is suspended in the annular space between the two cups and serves as the cathode. The magnesia crucible and the magnesia stirrer are highly vitrified bodies and are fabricated commercially.

Raw materials for the anode rod and cathode are purchased commercially and the actual parts are fabricated at Los Alamos.

The sodium chloride and potassium chloride reagents are AR grade and are purchased commercially. The salts are dried overnight under vacuum at $\sim 150^{\circ} \mathrm{C}$ and then cast into cylinders. Before use, a hole is drilled in one end of the salt rasting. 


\section{Operating Procedure}

The plutonium feed to the process is approximately a 4-kg cylindrical ingot. The ingot is placed in the inner cup of tae crucible. The crucible is loaded into the tantalum safety can, which is tnen placed in the stainless joading can. The assembly is then lowered into the furnace tube. The $1400-g$ salt casting is placed, hole up, on top of the inner crucible cup. The PuF 4 reagent is poured into the hole of the salt casting. The cover, containing the stirrer, cathode, and anode rod is then bolted to the furnaze tube. A vacium is pulled on the furnace tube and the assembly is checked for gas tightness. The furnace tube is $\therefore$ hen filled with argon gas to $4 \mathrm{psig}$. Thi crucible is heated at a rate or $50^{\circ} \mathrm{C} / \mathrm{7}$ to $750^{\circ} \mathrm{C}$.

The stirrer, cathode, and anode risds are lowered into position. The actual electrorefining process is accomplished by stirring at $800 \mathrm{rpm}$ and passing a dc current between anode and cathode. This electrorefining is preceded by a preequilibration and pre-electrolysis trestment that purifies the electrolyte (see Ref. 1). As plutonium is dissolved at the anode, the level of metal in the inner cup drops. Plitonium ions are reduced to metal on the cylindrical tungsten cathode. The plutonium drips of the bottom of this cylinder in large globules and collects in the annulus between the sinall and large crucibles. The progress of a run is monitored automatically by the back EMF Sampling Unit. 6 This simple device operates by interrupting the dc current prriodically and measuring the polarization potential of the chemical cell

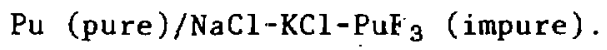

If the polarization potential exceeds a preset value, the dc current stays off. Thus, the electrorefining is terninated automatically. This measuring device permits unattended operation of the electrorefining process and terminates a run before impurities are dissolved. Upon completion of the electrorefining, thi? stirrer, anode rod, and cathode cylinder are raised from the meit and heating is discontinued. After cooling and unloading, the metal ring product is isolated from the crucible and salt. (A typical ring is shown in Fig. 7.) The anode residue and the salt-crucible residues aris processed by aqueous methods.

Typical conditions for a 4-kg scale electrorefining are given in Table III. The anode feed weighs $4100 \mathrm{~g}$ and contains $4000 \mathrm{~g}$ plutonium. The amcunt of PuF 4 


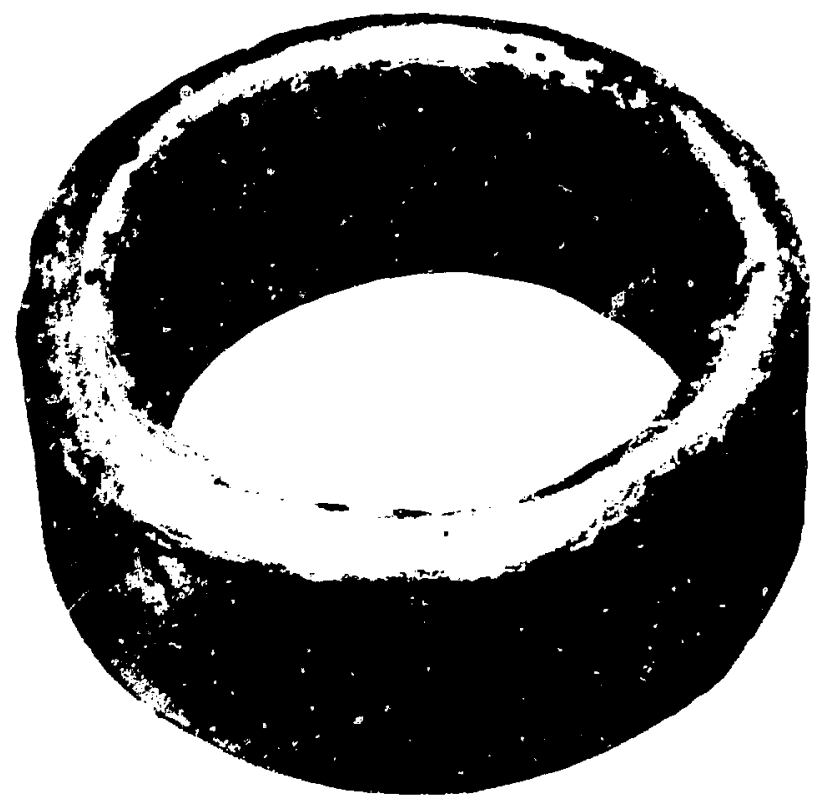

M

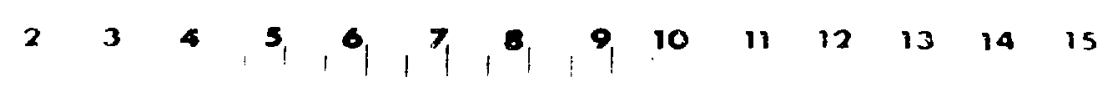

Fig. 7. Typical electrorefining product ring.

TABLE III

TYPICAL CONDITIONS FOR ELECTROREFINING

(4-kg Scale)

$\begin{array}{lr}\text { Weight of impure Pu, } 8 & 4100 \\ \text { Weight of NaCl-KCl, \& } & 1400 \\ \text { Weight of } \mathrm{PuF}_{4}, 8 & 120 \\ \text { Temperature, }{ }^{\circ} \mathrm{C} & 750 \\ \text { Current, A } & 20 \\ \text { Fu Collection rate, } 8 / \mathrm{h} & 59\end{array}$


added is determiner, by the requirements for americium removal. (For a detailed discussion of lis point, see Ref. 1.) The maximum direct current used is $30 \mathrm{~A}$. The actual curent used for any particilar run is calculated to permit termination of the run at d convenient time (Note. The units are manned on a 40-hour weck.) For most runs, the current is approximately $20 \mathrm{~A}$.

\section{E. Discussion and Results}

A typical material balance for a $4-\mathrm{kg}$ electrorefining run using an impure. Pu-1 wt\% Ga alloy feed is given in Table IV. The product yield is $82.5 \%$ $(100 \times 3300 / 4000)$. The fraction of anode depletion is 0.90 [(4000-400)/4000]. The metal coliection yield is $91.7 \%$ [100 x 3300/(4000-400)].

As discussed in Ref. 1, product yields are a function of anode depletion anit metal collection (that is, Product Yield $=0.90 \times 91.7 \%=82.5 \%$ ). For che case of a Pu-1 wt\% Ga anode, the maximum depletion that can be expected is 0.90. ${ }^{6}$ This results from the fact thas the alloy becomes solid when $90 \%$ of the plutonium has been dissolved anodically. One can expect much larger depletion values for impure alpha phase anodes that contain a liquid phase at high depletion values. ${ }^{1}$ Collection yields, on the sther hand, are a function of several variables ${ }^{1}$ and usually range from $90 \mathrm{t} \% 9.5 \%$. The plutonium product, which is no:

TABLE IY

TYPICAL PLUJDONIU: MATERIAL BALANCE, ELECTROREFINING, IMPSRE Pu-i WITHOUT GA FEED

Plutonium Into Run, \& Pu

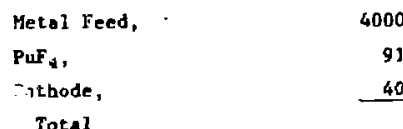

Plutonium Out of Run, 8 Pu

Pure Pu Product

Ring

Catbode

3300

Residues

Anode 400

Salt \& Crucible 391

Total

4131 
collected, exists in several forms. Host of it remains in the product collection zone as unconsolidated plutonium shot. Some metal reacts with the crucible wall to which it adheres. A smaller amount is unreduced $\mathrm{Pu}^{+3}$.

Purification results from a quite impure metal feed are given in Table $V$. (Typical results are given in Sec. V.) This table emphasizes the tremendous purification capabilities of the electrorefining process. Product purîy is essentially insensitive to the purity of the feed metal. The only real requirement for the feed is that it be molten or contain a single liquid and solid phase at the temperature of the electrorefining. For discussion of this point, see Refs. 1 and 6 .

TABLE $\mathrm{V}$

PURIFICATION OF PLUTONIUM METAL, RESULTS WITH AN IMPURE FEED

\begin{tabular}{|c|c|c|}
\hline \multirow[b]{2}{*}{ Eiement } & \multicolumn{2}{|c|}{ g Element $/ 10^{6} \mathrm{~g} \mathrm{Pu}$} \\
\hline & Feed & Product \\
\hline $\mathrm{Mg}$ & $10 r$ & 2 \\
\hline Al & 200 & 1 \\
\hline $\mathrm{Si}$ & 50 & 5 \\
\hline $\mathrm{Ca}$ & 100 & $<3$ \\
\hline$C_{r}$ & 1000 & $<0.5$ \\
\hline Mn & 100 & $<0.1$ \\
\hline $\mathrm{Fe}$ & 5000 & 5 \\
\hline $\mathrm{Ni}$ & 200 & 2 \\
\hline $\mathrm{Cu}$ & 100 & 1 \\
\hline Za & 1000 & $<0.5$ \\
\hline Mo & 1000 & $<0.5$ \\
\hline Cd & 2000 & $<0.5$ \\
\hline Sn & 2000 & $<0.5$ \\
\hline $\mathbf{P b}$ & 2000 & $<0.5$ \\
\hline$w$ & $<10$ & 60 \\
\hline Th & 140 & 4 \\
\hline $\mathrm{u}$ & 80 & 14 \\
\hline An & 140 & 20 \\
\hline Ga & $1.04 \times 10^{4}$ & $<25$ \\
\hline Po, wty & 97.0 & 99.98 \\
\hline
\end{tabular}


V. CONVERSION OF IMPIRE PLUTONIA TO HIGH-PURITY METAL

The flowsheet fer the conversion of impure plutonia to high-purity metal is given in Fig. 8. Small cans of $\mathrm{PuO}_{2}$, typically $900 \mathrm{~B}$, are combined to make a

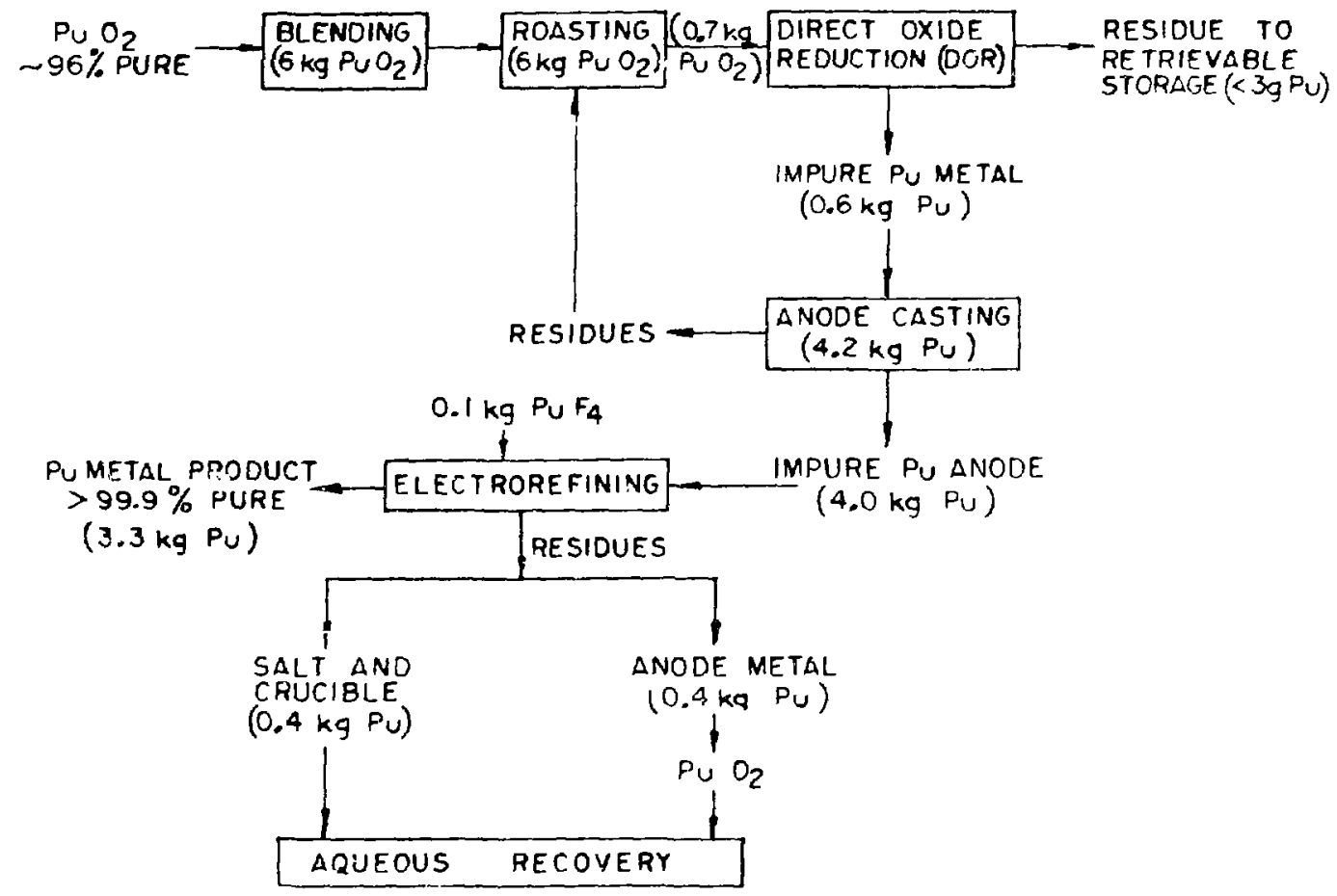

Fig. 8. Conversion of impure plutonia to high-purity metal.

$6-\mathrm{kg}$ lot. The $6-\mathrm{kg}$ lot is then heated in air at $800^{\circ} \mathrm{C}$ for 5 hours to ensure the absence of water, sulfate, and adsorbed gases. Seven hundred gram batches of oxide are aliquoted for oxide reduction. Each reduction yields approximately $600 \mathrm{~g}$ of impure metal. Approximately seven metal buttons are combined and cast under vacuum into a $4-\mathrm{kg}$ cylinder that serves as feed to the electrorefining process. Residues from the casting step, about $5 \%$ of the casting feed, are recycled to the roasting operation. The electrorefining yields a product $r i n g$ and two types of residues, an anode containing virtually all of the impurity elements and a crucible-salt residue containing plutonium and americium. The residues are recyled through aqueous recovery. Approximately $3.3 \mathrm{~kg}$ of pure metal product are produced per run. Because anode casting residues are recycled to the roasting 
operation, the only losses in the process are the residues from DOR and ER. The overall product yield is therefore $82 \%(82.5 \% \times 0.995)$. A plutonium material balance for the combined flowsheet is given in Table VI.

TABLE VI

SUMMARY OF PROCESS YIELDS, DOR/ER FROCESS

DOR

Oxide Feed

Bulk Wt (g) 4979 (4732 new + 247 casting recycle)

$\mathrm{FuO}_{2}$ Wt $(\mathrm{g}) \quad 4800(4562$ new +238 casting recycle $)$

$\mathrm{Pu}$ Wt (g) 4231 (4021 new + 210 casting rerycle)

Product Plus Residues

$$
\begin{array}{lc}
\text { Product, } \mathrm{Pu}(\mathrm{g}) & 4210(99.5 \% \text { yield }) \\
\text { Residue, } \mathrm{Pu}(\mathrm{g}) & 2 \mathrm{I}
\end{array}
$$

\section{ANODE CASTING}

Feed, $g$ P $\mathrm{P}_{\jmath}$

4210

Producl Ingot, $\mathrm{g} \mathrm{Pu}$

4000 (95\% yield)

Residue, $8 \mathrm{Pu}$

210 (recycled to DOR oxide feed)

\section{ELECTROREF IN ING}

Feed Ingot, $\mathrm{g} \mathrm{Pu}$

4000

product ring, $8 \mathrm{Pu}$

$3300(82.5 \%$ yield)

Residues, $8 \mathrm{Pu}$

700

The flowsheet of Fig. 8 has been used to process approximately $250 \mathrm{~kg}$ of impure oxide to high-purity metal. Typical purification results are given in Table VII where the purities of an impure sxide feed, impure metal, and high purity product metal are compared. The table demonstrates the excellent purification that can be achieved in the combined DOR/ER process. 
TABLE VII

COMPARISON OF PURITIES OF OXIDE FEED, DOR METAL, AND

ER METAL PRODUCT, (Run PMR 162)

\section{Element}

B

Na

19

41

$\mathrm{Si}$

K

Ca

$\mathrm{Ti}$

$\mathrm{Cr}$

Mn

Fe

N

$\mathrm{Cu}$

$Y$

2 r

Nb

Mo

Ta

W

$\mathrm{Pb}$

Th

U

c

Am

$\mathrm{Pu}$ g Element/10 8 Sample

\section{Oxide-Feed}

$>150$

$>233$

$>375$

500

283

$>100$

$>750$

32

317

20

$>1500$

880

24

$>180$

$>450$

85

121

$>500$

$>500$

38

421

656

78

655

82.23 ( $93.29 \%$ pure) 98.47
ER Product

$>150$

10

300

500

1400

50

15

100

$<3$

$<5$

$<5$

$\therefore 1$

$>1500$

$<5$

940

$<5$

$<1$

$<25$

500

$<100$

60

$<10$

200

$<3$

$>500$

$<100$

$>500$

100

$<5$

$<5$

30

7

25

219

99.96 
VI. FUTURE WORK

Work is in progress to improve the efficiencies of both the DOR and electrorefining processes.

The present DOR prncess would be improved by

(a) recycling the $\mathrm{CaCl}_{2}-\mathrm{CaO}$ salt residues (presently these residues are sent to retrievable storage),

(b) increasing the scale of the reduction,

(c) decreasing the time required for a reduction.

Detailed recommendations for improving the electrorefining process are discussed in Ref. 1. These recommendations include

(a) increasing the scale to $6 \mathrm{~kg}$ of plutonium,

(b) decreasing the process time,

(c) improving the process efficiency by increasing the collection efficiency and anode depletion, and

(d) developing pyrochemical procedures ${ }^{R}$ for the recyrle of process residues.

\section{REFERENCES}

1. L. J. Mullins and A. N. Morgan, "A Review of Operating Experience at the Los Alamos Plutonium Electrorefining Facility, 1963-1967" Los Alamos National Laboratory report LA 8943 (1981),

2. L. J. Mullins and C. L. Foxx, "Direct Reduction of ${ }^{238} \mathrm{PuO}_{2}$ and ${ }^{239} \mathrm{PuO}_{2}$ to Metal", Los Alamos National Laboratory report LA 9073 (in press).

3. L. J. Mullins and A. N. Morgan, "Reduction of $\mathrm{PuO}_{2}$ to Metal", Los Alamos National Laboratory internal documents, CMB-11 Procedures, CMB-11-77-37 Rev O (1977) and 420-MPP-ROI (1978).

4. Science, 211, January 9, 1981.

5. D. A. Wenz, I. Johnson, and R. D. Wolson, " $\mathrm{CaCl}_{2}-\mathrm{Rich}$ Region of the $\mathrm{CaCl}_{2}$ $\mathrm{CaF}_{2}$-CaO System," J. Chem. Eng. Data, 14, [2], 250-252 (1969).

6. L. J. Mullins and J. A. Leary, "Fused-Salt Electrorefining of Molten Putoniun and Its Alloys by the LALEX Process," I\&EC Process Design and Development 4 , 394-400 (1965). 
7. E. L. Christensen and W. J. Maraman, "Plutonium Processing at the Los Alamos Scientific Laboratory," Los Alamos Scientific Laboratory report LA-3542. (1969).

8. J. B. Knighton, R. G. Auge, and J. C. Brown, "Purification of Plutonium by Oxidation-Reduction Process," Rockwell International report RFP-D 529 (1972). 